\title{
Improved Mortality Risk Stratification in Normotensive Patients with Acute Pulmonary Embolism Using Heart-Type Fatty Acid-Binding Protein
}

\author{
DAN OCTAVIAN NISTOR ${ }^{1,2 *}$, ADINA HUTANU ${ }^{3,4}$, CLAUDIA BANESCU ${ }^{4}$, FLAVIUS TOMSA ${ }^{2}$, \\ GALAFTEON OLTEAN ${ }^{1}$, MIHAELA MARIA OPRIS ${ }^{2}$, ILEANA VOICHITA SIRBU ${ }^{1,2}$ \\ ${ }^{1}$ University of Medicine and Pharmacy Targu Mures, Department M3, 38 Gh. Marinescu Str., 540136, Targu Mures, \\ Romania \\ ${ }^{2}$ Institute for Emergency Cardiovascular Disease and Transplant, Targu Mures, 50 Gh. Marinescu Str., 540142, Targu \\ Mures, Romania \\ ${ }^{3}$ University of Medicine and Pharmacy Targu Mures, Department M2, 38 Gh. Marinescu Str., 540136, Targu Mures, \\ Romania \\ ${ }^{4}$ Center for Advanced Medical and Pharmaceutical Research, Targu Mures, 38 Gh. Marinescu Str., 540136, Targu \\ Mures, Romania
}

\begin{abstract}
We performed a prospective, observational study on consecutive non-high-risk patients with APE in order to assess the prognostic value of laboratory markers, including the novel heart-type fatty acid-binding protein (H-FABP), for predicting a composite end point of 30-day mortality or hemodynamic collapse. A total of 61 patients were included and H-FABP was significantly higher in the composite end-point group (9.303 vs. 4.761, p=0.046) and proved to identify more accurately patients at increased risk.
\end{abstract}

Keywords: Pulmonary embolism, heart type fatty acid binding protein, risk assessment

Acute pulmonary embolism (APE) is the third most frequent cardiovascular disease and a major cause of mortality and morbidity, with an annual incidence of $100-200$ patients per 100,000 inhabitants [1]. Current management and treatment guidelines recommend initial risk stratification of all patients in order to guide consequent therapies [2]. This is performed using clinical variables, laboratory cardiac biomarkers and right ventricular (RV) dysfunction identification by an imaging test and the calculation of mortality risk scores, like the pulmonary embolism severity index (PESI) and its simplified version (sPESI) [2]. This risk stratification divides patients into low, intermediate and high-risk classes and is essential because patients at high mortality risk benefit from aggressive reperfusion therapy. Patients with APE that are considered at a non-high-risk of death, have an early 30-day mortality of 3-15\% [3]. This suggests that these patients have different degrees of disease severity and present variable complications during their clinical course and that some of them share many characteristics with the patients considered at high-risk. Laboratory cardiac biomarkers like N-terminal pro-brain natriuretic peptide (NT-proBNP) and troponins are currently used in risk stratification [4], but some recent studies have focused on another biomarker, heart-type fatty acid-binding protein (HFABP), a low molecular weight protein which is present in high amounts in the cytosol of cardiomyocytes and functions as a cell membrane stabilizer. It has an acute rise as early as 30 minutes after myocardial injury, has a $6-8 \mathrm{~h}$ peak and disappears in 24-30 h and, subsequently has a more favorable dynamic curve for identifying acute cardiac injury than troponins [5]. In APE patients, its rise has also been attributed to right ventricular wall stress caused by an acute increase in afterload [6].

The aim of the study was to assess the prognostic value of laboratory markers, including H-FABP, in predicting adverse events in non-high-risk patients with APE.

\section{Experimental part \\ Methods}

We performed a prospective, observational study of consecutive non-high-risk patients with APE, who were admitted to hospital during a period of 12 months. The study protocol was approved by the local ethics committee. The diagnosis was confirmed by computer tomographic angiography with contrast medium, which identified 1 or more filling defects of the pulmonary arteries. Initial mortality risk assessment was performed according to current guideline recommendations and patients that presented with a systolic blood pressure of $<90 \mathrm{mmHg}$, a persistent 40 $\mathrm{mmHg}$ drop for at least 15 minutes or other signs of hypoperfusion were considered at high-risk and were excluded from the study.

Clinical data was recorded for all patients, including age, sex, medical history and vital signs, and individual risk scores were calculated. Blood analyses were performed on all patients in the first 24 hours after admission. Patients were included after signing the informed consent form included in the study protocol.

*email: dr.dan.nistor@gmail.com, Phone: +40745758678 
For blood analyses, peripheral venous samples were collected and analyzed using a table-top chemiluminescence immunoassay analyzer (Pathfast, LSI Medience Corporation, Tokyo, Japan) for determining troponin I and NTproBNP levels. For H-FABP value determination, blood was separately collected in clot activator tubes, left for 20 minutes at room temperature for clot formation and centrifuged at 3500 RPM. Serum samples were aliquoted and stored at $-80^{\circ} \mathrm{C}$ immediately until analysis. Serum levels of human H-FABP were measured using a quantitative sandwich enzyme-linked immunoassay (Thermo Fisher Scientific, Frederick, MD, USA) according to the manufacturer's instructions. The specific antibody for H-FABP, which is fixed on the microwells, is able to recognize and capture the H-FABP from the samples. The addition of the second biotinylated antibody and substrate allowed revealing the amount of the H-FABP from the serum sample. The concentration of the analyte was calculated on the 4-parameter logistic curve as proportional to the intensity of the signal and the calibration range was between 1.5 and $200 \mathrm{ng} / \mathrm{mL}$. The coefficient of variation for intra-assay precision was $<10 \%$ and for inter-assay precision was $<12 \%$. Other laboratory values were determined using standard techniques and validated equipment.

Patients were followed for 30 days after admission and the composite endpoint of 30-day APE-related death or hemodynamic instability, measured by the need for temporary use of inotropic drugs, was recorded. The treatment, including the decision to use these drugs, was conducted by the attending physician, in line with current treatment guideline recommendations. The study protocol was approved by the local ethics committee.

The numerical data collected was analyzed for normal distribution using the Kolmogorov-Smirnov test. For parametric data, the Student's $t$-test was used to compare means, and for non-parametric data the Mann-Whitney U test was used. For discrete variable comparison, the chi-squared or Fisher's exact test were used. Receiver operator characteristic (ROC) analysis was performed for predicting the composite endpoint and the area under the curve (AUC) with $95 \% \mathrm{CI}$ and significance $\mathrm{p}$ value was calculated. A $\mathrm{p}$ value of $<0.05$ was considered significant and for parameters with a significant AUC, a cut-off value with the best sensitivity and specificity was determined using the Youden index. Statistical analysis was performed using SPSS v20 software (IBM, Armonk, NY, USA).

\section{Results and discussions}

During the 12 months enrollment period, 61 non-high-risk APE patients matched our criteria and were included in the study. During follow-up, a number of 9 composite endpoint events were recorded, with 2 patients (3.3\%) suffering APE-related deaths within the first 30 days and 7 patients (11.5\%) needing inotropic drug support to maintain adequate tissue perfusion. All patients were treated according to guideline recommendations, with initial parenteral anticoagulation with aPTT dose-adjusted unfractionated heparin or weight dose-adjusted low molecular weight heparin, followed by oral anticoagulation, either with INR dose-adjusted vitamin K antagonist or non-vitamin $\mathrm{K}$ oral anticoagulants and none received systemic thrombolysis.

Patients were mostly elderly (mean age 69 years), male (55\%) and presented on average with a normal blood pressure $(129 \mathrm{mmHg})$, an elevated heart rate $(95 \mathrm{bpm})$ and a normal peripheral oxygen saturation (94\%). Laboratory analysis showed on average positive cardiac biomarkers and normal creatinine and hemoglobin levels. There was an increased prevalence of some risk factors like previous immobilization (31\%), chronic obstructive pulmonary disease (18\%) and heart failure (26\%) and most patients had a low mortality risk score (sPESI $\leq 1$ points). The patients' baseline characteristics, risk score and laboratory findings are presented in table 1.

Patients were divided into 2 groups according to the presence or absence of the composite endpoint. Regarding clinical characteristics, the patients in the endpoint group were on average of similar age (endpoint group vs. nonendpoint group 72.7 vs. $68.9, \mathrm{p}=0.387$ ), more often female ( 78 vs. $38 \%, \mathrm{p}=0.065)$, had a higher heart rate (108 vs. 93 bpm, $\mathrm{p}=0.021)$, a lower systolic blood pressure $(107 \mathrm{vs} .133 \mathrm{mmHg}, \mathrm{p}=0.008)$ and a lower peripheral oxygen saturation ( 80 vs. $95 \%, \mathrm{p}<0.001)$. Also, they had more often a history of heart failure (56 vs. $21 \%, \mathrm{p}=0.045$ ), but showed no difference in the presence of other risk factors. The sPESI was significantly higher in the composite endpoint group ( $\mathrm{p}<0.001)$, with an average score of 3.0 vs. 0.8 points.

Laboratory analysis showed significantly higher values for all the cardiac markers in the composite endpoint group with a mean H-FABP of 9.303 vs. 4.761, $\mathrm{p}=0.046$, Troponin I of 0.121 vs. $0.013, p=0.037$ and NT-proBNP of 18408 vs. $1628, \mathrm{p}=0.027$. However, no significant differences were found between the 2 groups for non-cardiac specific markers with creatinine levels of 1.07 vs $1.04, p=0.344$ and hemoglobin of 13.3 vs. $13.6, p=0.624$. All the correlations with the composite endpoint are presented in table 2.

Table 1

PATIENT CHARACTERISTICS

\begin{tabular}{|l|l|}
\hline Characteristic, unit & Value \\
\hline Age, years & $69.5 \pm 12$ \\
\hline Sex, pts. (\% of total) & \\
Male & $34(55 \%)$ \\
Female & $27(45 \%)$ \\
\hline Systolic Blood Pressure, $\mathrm{mmHg}$ & $129 \pm 28$ \\
\hline Heart Rate, bpm & $96 \pm 18$ \\
\hline Peripheral $\mathrm{O}_{2}$ Saturation, \% & $94(88-96)$ \\
\hline
\end{tabular}




\begin{tabular}{|l|l|}
\hline H-FABP, $\mathrm{ng} / \mathrm{mL}$ & $4.873(3.129-8.404)$ \\
\hline Troponin I, ng/mL & $0.024(0.006-0.088)$ \\
\hline NT-proBNP, pg/mL & $2785(499-7783)$ \\
\hline Creatinine, $\mathrm{mg} / \mathrm{dL}$ & $1.05(0.86-1.27)$ \\
\hline Hemoglobin, g/dL & $13.6 \pm 1.8$ \\
\hline Risk factors, pts. (\% of total) & \\
Previous immobilization & $19(31 \%)$ \\
Active cancer & $6(10 \%)$ \\
COPD history & $11(18 \%)$ \\
HF history & $16(26 \%)$ \\
\hline sPESI 0 points, pts. (\% of total) & $22(36 \%)$ \\
1 point & $21(34 \%)$ \\
2 points & $9(15 \%)$ \\
3 points & $6(10 \%)$ \\
4 points & $3(5 \%)$ \\
5-6 points & $0(0 \%)$ \\
\hline
\end{tabular}

Values are expressed as number of patients (percent), mean \pm SD for normal distribution or median $\left(25^{\text {th }}-75^{\text {th }}\right.$ percentile $)$ for non-normal distribution.

COPD chronic obstructive pulmonary disease, HF heart failure, H-FABP

heart-type fatty acid-binding protein, sPESI simplified pulmonary embolism severity index

Table 2

CORRELATIONS WITH THE COMPOSITE ENDPOINT

\begin{tabular}{|c|c|c|c|}
\hline Characteristic, unit & $\begin{array}{l}\text { Non-endpoint patients } \\
(\mathrm{n}=52)\end{array}$ & $\begin{array}{l}\text { Endpoint patients } \\
(\mathbf{n}=9)\end{array}$ & p value \\
\hline Age, years & $68.9 \pm 12$ & $72.7 \pm 11$ & 0.387 \\
\hline Sex Male/Female, pts. & $32 / 20$ & $2 / 7$ & 0.065 \\
\hline Systolic Blood Pressure, $\mathrm{mmHg}$ & $133 \pm 26$ & $107 \pm 28$ & 0.008 \\
\hline Heart Rate, bpm & $93 \pm 16$ & $108 \pm 23$ & 0.021 \\
\hline Partial Arterial $\mathrm{O}_{2}$ Saturation, $\%$ & $95(91-97)$ & $80(78-88)$ & $<0.001$ \\
\hline H-FABP, ng/mL & $4.761(3.089-7.410)$ & $\begin{array}{ccc}9.303 & (4.224 & - \\
18.215) & & \\
\end{array}$ & 0.046 \\
\hline Troponin I, ng/mL & $0.013(0.005-0.061)$ & $0.121(0.024-0.196)$ & 0.037 \\
\hline NT-proBNP, pg/mL & $1628(439-4896)$ & $\begin{array}{ccc}18408 & (6140 & - \\
30000) & & \\
\end{array}$ & 0.027 \\
\hline Creatinine, $\mathrm{mg} / \mathrm{dL}$ & $1.04(0.86-1.26)$ & $1.07(0.87-1.83)$ & 0.344 \\
\hline Hemoglobin, g/dL & $13.6 \pm 1.8$ & $13.3 \pm 1.6$ & 1.000 \\
\hline $\begin{array}{l}\text { Risk factors, pts. (\% of total) } \\
\text { Previous immobilization } \\
\text { Active cancer } \\
\text { COPD history } \\
\text { HF history } \\
\end{array}$ & $\begin{array}{l}14(27 \%) \\
5(10 \%) \\
9(17 \%) \\
11(21 \%) \\
\end{array}$ & $\begin{array}{l}5(56 \%) \\
1(11 \%) \\
2(22 \%) \\
5(56 \%)\end{array}$ & $\begin{array}{l}0.121 \\
1.000 \\
0.659 \\
0.045 \\
\end{array}$ \\
\hline $\begin{array}{l}\text { sPESI average } \\
0 \text { points, pts. }(\% \text { of total }) \\
1 \text { point } \\
2 \text { points } \\
3 \text { points } \\
4 \text { points } \\
5-6 \text { points }\end{array}$ & $\begin{array}{l}0.8 \\
22(42 \%) \\
21(40 \%) \\
6(12 \%) \\
3(6 \%) \\
0(0 \%) \\
0(0 \%)\end{array}$ & $\begin{array}{l}3 \\
0(0 \%) \\
0(0 \%) \\
3(33 \%) \\
3(33 \%) \\
3(33 \%) \\
0(0 \%)\end{array}$ & $<0.001$ \\
\hline
\end{tabular}

Values are expressed as number of patients (percent), mean \pm SD for normal distribution or median (25th-75th percentile) for non-normal distribution. COPD chronic obstructive pulmonary disease, HF heart failure, H-FABP heart-type fatty acid-binding protein, sPESI simplified pulmonary embolism severity index

The ROC curve of H_FABP showed a good predictive value for the composite end-point with an AUC of 0.709, (0.513-0.905 95\% CI) and a significant $p$ value of 0.046. Using the Youden index, the point on the curve with optimal specificity and sensibility was determined for H-FABP, $6 \mathrm{ng} / \mathrm{mL}$, with the ROC curve presented in figure 1 . 


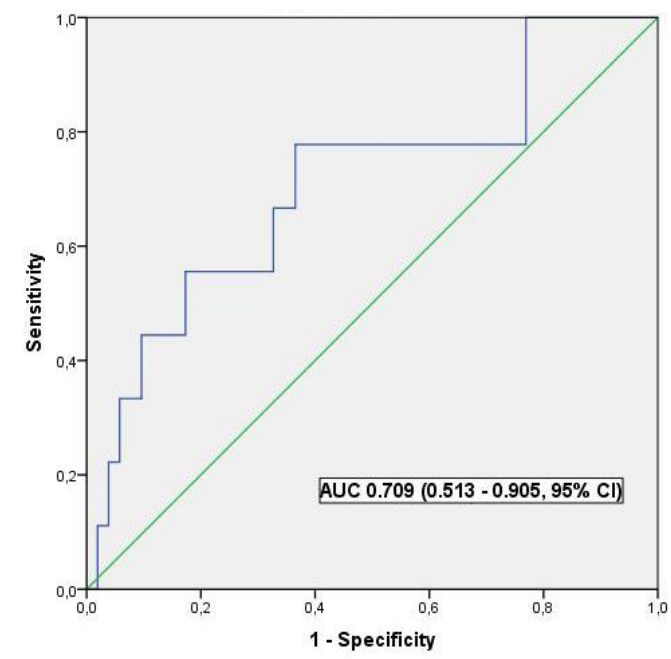

Fig. 1. ROC curve of H-FABP predictive power

Using the cut-off value of $6 \mathrm{ng} / \mathrm{mL}$ for the H-FABP test, we identified patients with a positive or negative test (23 vs. $38 \mathrm{pts}$ ) which showed an improved identification of patients at risk than SPESI (23.1 vs $26.1 \%$ ) with a significant $\mathrm{p}$ value of 0.05 , as shown in figure 2 .

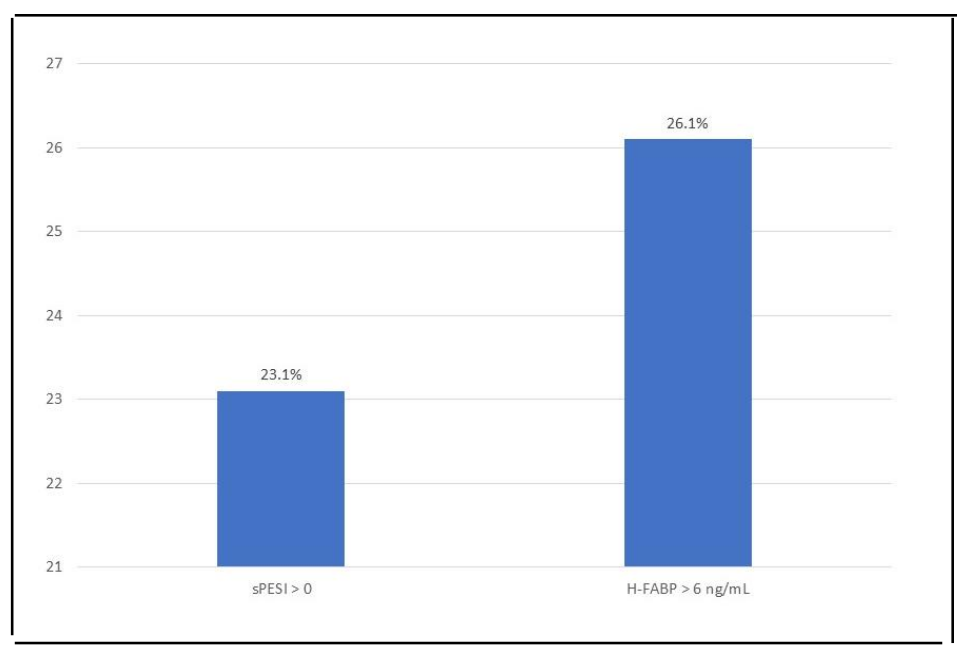

Fig. 2. Death or hemodynamic instability in normotensive patients with acute pulmonary embolism

APE represents a major cause of global mortality and morbidity, even with modern diagnostic and treatment methods. Patient management is based on initial mortality risk stratification using the algorithm published in the recent guidelines on the diagnosis and management op APE [2]. Aggressive reperfusion therapy, either by systemic thrombolysis or by invasive procedures, is warranted for high-risk patients, but evidence suggests that these therapies could also help some patients from the non-high-risk group [7]. These patients, which are considered at an intermediate-high mortality risk, were the target of the landmark PEITHO trial [8], which analyzed the effects of systemic thrombolysis on patients with APE and both positive troponin and RV dysfunction. The results showed a benefit of reduced hemodynamic decompensation in some patients, but at the cost of an increased rate of major and intracranial bleeding events, that overweighed the total benefit. These findings were confirmed in other subsequent meta-analyses [9-12] and they raise the question that, if improved risk classification criteria for these patients could identify which of them are at higher risk, then the risk-benefit ratio could improve in favor of the more aggressive therapies.

Our population of patients with non-high-risk APE was divided into 2 groups according to the occurrence of death or necessity for inotropic drug support. The composite endpoint group patients presented many clinical signs of acute heart failure with a significantly higher heart rate, lower blood pressure and lower peripheral oxygen saturation. These clinical variables are all included in the recommended risk score, sPESI which, as a result, was on average markedly higher in this group (3.0 vs. 0.8).

The study was aimed at identifying patients at high mortality risk from the class of non-high-risk APE patients using modern diagnostic laboratory methods. Cardiac injury or stress biomarkers, which were initially developed for left heart diseases, are now also used to detect right ventricular impairment [13]. An elevated NT-proBNP value indicates the degree of hemodynamic alteration caused by RV dysfunction in APE. However, its predictive value for early mortality risk is low, especially when used in non-high-risk APE patients [14] and is mainly useful for 
identifying low risk patients in which an early discharge management strategy and outpatient treatment is more appropriate [15]. Our results indicated though a significantly higher NT-proBNP value in the composite endpoint group. Another myocardial injury marker, troponin I, has reported limited prognostic value in normotensive, nonhigh-risk APE patients [16,17]. In our population, the troponin values were markedly higher in the endpoint group.

H-FABP is a novel marker of myocardial injury which has been shown to increase in heart failure [18], has a proven prognostic value in acute coronary syndromes [19] and has also generated a lot of studies in the setting of APE. In the first studies of H-FABP in unselected APE patients, Kaczynska et al. [20] have demonstrated that an increased value of over $6 \mathrm{ng} / \mathrm{mL}$, recorded in the first 10 days after symptom onset, is the only 30-day APE-related death predictor among cardiac biomarkers, with an HR of 1.02. In a later study on all risk APE patients, Puls et al. [21] found a positive H-FABP, using the same cut-off value, as a good discriminant of patients with a complicated clinical course and that all patients with a negative test presented favorable 30-day outcomes. Moreover, at the multivariable regression analysis, only H-FABP, as opposed to troponins or NT-proBNP, had predictive power for adverse outcomes (OR 36.74, $\mathrm{p}<0.0001$ ).

In a study of normotensive non-high-risk APE patients, Dellas et al. [22], using the same $6 \mathrm{ng} / \mathrm{mL}$ cut-off value, associated a positive H-FABP test with a 36.6-fold increase in the risk of death or clinical complications, while only $<1 \%$ of patients with a negative test presented complications, with a negative predictive value of $99 \%(\mathrm{p}<0.001)$. These results were in line with those of Boscheri et al. [6], which reported a negative H-FABP test, in intermediate risk APE patients, as an ideal predictor for low risk of death or complicated in-hospital course $(\mathrm{p}<0.005)$. Another study, performed on 161 consecutive hemodynamically stable APE patients, demonstrated a positive H-FABP test as an independent predictor of early mortality, with an OR of 27.1, $\mathrm{p}=0.001$ [23]. These findings have also been confirmed in recent meta-analyses that demonstrated H-FABP as a marker of increased 30-day death or clinical complications risk in non-high-risk APE patients [24-27]. In our study population, H-FABP was significantly higher in the composite endpoint group with an average of $9.303 \mathrm{ng} / \mathrm{mL}$ and showed a significantly greater sensibility for identifying patients at increased risk of 30-day mortality or hemodynamic instability.

\section{Conclusions}

In non-high-risk APE patients, an elevated H-FABP value is associated with an increased risk for early mortality or hemodynamic instability. H-FABP testing can improve the identification of patients at an increased risk of 30-day APE-related death or need for inotropic drugs from the non-high-risk APE class.

Acknowledgements: This project was funded through an Internal Research Grant by The University of Medicine and Pharmacy Targu Mures, Romania, No. 17800/22.12/2015.

\section{References}

1.HEIT, J.A., Arterioscler Thromb Vasc Biol; 28(3), 2008, p. 370-372.

2.KONSTANTINIDES, S., TORBICKI, A., AGNELli, G., DANCHIN, N., FITZMAURICE, D., GALIÈ, N., GIBBS, J.S., HUISMAN, M.V., HUMBERT, M., KUCHER, N., LANG, I., LANKEIT, M., LEKAKIS, J., MAACK, C., MAYER, E., MENEVEAU, N., PERRIER, A., PRUSZCZYK, P., RASMUSSEN, L.H., SCHINDLER, T.H., SVITIL, P., VONK NOORDEGRAAF, A., ZAMORANO, J.L., ZOMPATORI, M., Eur Heart J; 35(43), 2014, p. 3033-3069.

3.TORBICKI, A., PERRIER, A., KONSTANTINIDES, S., AGNELli, G., GALIÈ, N., PRUSZCZYK, P., BENGEL, F., BRADY, A.J., FERREIRA, D., JANSSENS, U., KLEPETKO, W., MAYER, E., REMY-JARDIN, M., BASSAND, J.P., Eur Heart J; 29(18), 2008, p. 22762315.

4.DINESCU, V.C., PUIU, I., DINESCU, S.N., TUDORASCU, D.R., BICA, E.C., VASILE, R.C., BUNESCU, M.G., ROMANESCU, F.M., CIOATERA, N., ROTARU, L.T., MUSTAFA, R.E., FLORESCU, C., Rev Chim (Bucharest); 70, no. 1, 2019, p. 63-68.

5.COLLI, A., JOSA, M., POMAR, J.L., MESTRES, C.A., GHERLI, T., Cardiology; 108, 2007, p. 4-10.

6.BOSCHERI, A., WUNDERLICH, C., LANGER, M., SCHOEN, S., WIEDEMANN, B., STOLTE, D., ELMER, G., BARTHEL, P., STRASSER, R.H., Am Heart J; 160(2), 2010, p. 294-300.

7.HALMACIU, I., SUCIU, BA., FODOR, D., GODJA, D., TRAMBITAS, C., VUNVULEA, V., BRINZANIUC, K., MOLNAR, C., Mat. Plast; 55, no. 2, 2018, p. 207-210.

8.MEYER, G., VICAUT, E., DANAYS, T., AGNELLI, G., BECATTINI, C., BEYER-WESTENDORF, J., et al. N Engl J Med; 370(15), 2014, p. $1402-1411$.

9.SUCIU, B.A., HALMACIU, I., BUD, V., COPOTOIU, C., FODOR, D.R.P., TRAMBiTAS, C., VUNVULEA. V., MOLNAR, C., BRINZANIUC, K., Mat Plast, 54, no. 3, 2017, p. 520-522.

10.CHATTERJEE, S., CHAKRABORTY, A., WEINBERG, I., KADAKIA, M., WILENSKY, R.L., SARDAR, P., KUMBHANI, D.J., MUKHERJEE, D., JAFF, M.R., GIRI, J., JAMA; 311(23), 2014, p. 2414-2421.

11.MARTI, C., JOHN, G., KONSTANTINIDES, S., COMBESCURE, C., SANCHEZ, O., LANKEIT, M., MEYER, G., PERRIER, A., Eur Heart J; 36(10), 2015, p. 605-614.

12.TRAMBITAS, C., POP, T.S., TRAMBITAS MIRON, A.D., DOROBANTU, D.C., BRINZANIUC, K., Rev Chim (Bucharest), 68, 2, 2017, p. 387-389.

13.GESZTELYI, R., KISS, Z., WACHAL, Z., JUHASZ, B., BOMBICZ, M., CSEPANYI, E., PAK, K., ZSUGA, J., PAPP, C., GALAJDA, Z., BRANZANIUC, K., PORSZASZ, R., SZENTMIKLOSI, A.J., TOSAKI, A., Arch Pharm Res; 36, 2013, p. $293-305$.

14.KUCHER, N., GOLDHABER, S.Z., Circulation; 108(18), 2003, p. 2191-2194.

15.AGTEROF, M.J., SCHUTGENS, R.E., SNIJDER, R.J., EPPING, G., PELTENBURG, H.G., POSTHUMA, E.F., HARDEMAN, J.A., VAN DER GRIEND, R., KOSTER, T., PRINS, M.H., BIESMA, D.H., J Thromb Haemost; 8(6), 2010, p. 1235-1241.

16.JIMENEZ, D., URESANDI, F., OTERO, R., LOBO, J.L., MONREAL, M., MARTI, D., ZAMORA, J., MURIEL, A., AUJESKY, D., YUSEN, R.D., Chest; 136(4), 2009, p. 974-982. 
17.POP, TS., POP, AM., TRAMBITAS MIRON, AD., BRINZANIUC, K., GURZU, S., TRAMBITAS, C., Mat Plast, 55, no. 4, 2018, p. 691695.

18.ARIMOTO, T., TAKEISHI, Y., SHIGA, R., J Card Fail; 11, 2005, p. 56-60.

19.O'DONOGHUE, M., DE LEMOS, J.A., MORROW, D.A., MURPHY, S.A., BUROS, J.L., CANNON, C.P., SABATINE, M.S., Circulation; 114, 2006, p. 550-557.

20.KACZYÑSKA, A., PELSERS, M.M., BOCHOWICZ, A., KOSTRUBIEC, M., GLATZ, J.F., PRUSZCZYK, P., Clin Chim Acta; 371(1-2), 2006, p. 117-123.

21.PULS, M., DELLAS, C., LANKEIT, M., OLSCHEWSKI, M., BINDER, L., GEIBEL, A., REINER, C., SCHÄFER, K., HASENFUSS, G., KONSTANTINIDES, S., Eur Heart J; 28(2), 2007, p. 224-229.

22.DELLAS, C., PULS, M., LANKEIT, M., SCHAFER, K., CUNY, M., BERNER, M., HASENFUSS, G., KONSTANTINIDES, S., J Am Coll Cardiol; 55(19), 2010, p. 2150-2157.

23.LANGER, M., FORKMANN, M., RICHTER, U., TAUSCHE, A.K., SVERIC, K., CHRISTOPH, M., IBRAHIM, K., GÜNTHER, M., KOLSCHMANN, S., BOSCHERI, A., BARTHEL, P., STRASSER, R.H., WUNDERLICH, C., J Crit Care; 35, 2016, p. 174-179.

24.RUAN, L.B., HE, L., ZHAO, S., ZHU, P., LI, W.Y., Chest; 146(6), 2014, p. 1462-1467.

25.LIU, M., YUAN, X., QIU, X., SHAN, X., LIN, D., ZHU, L., Thromb Res; 135(1), 2015, p. 20-25.

26.AL HUSSEIN, H., HARPA, M., MOVILEANU, I., AL HUSSEIN, H., SUCIU, H., BRANZANIUC, K., SIMIONESCU, D., Rev Chim (Bucharest), 70, no. 5, 2019, p. 1826-1828.

27.BAJAJ, A., RATHOR, P., SEHGAL, V., KABAK, B., SHETTY, A., AL MASALMEH, O., HOSUR, S., Lung; 193(5), 2015 , p. 639-651.

Manuscript received: 22.07 .2019 